\title{
Konsep dan Operasionalisasi Model SAMR dalam Pembelajaran PAI
}

\author{
Moch. Khotibul Ummam \\ Pascasarjana UIN Sunan Ampel Surabaya \\ E-mail: khotibulummam22@gmail.com \\ Lailiyatul Maulidah \\ Pascasarjana UIN Sunan Ampel Surabaya \\ E-mail: ellailiya@gmail.com \\ Mochammad Syihabbudin \\ Pascasarjana UIN Sunan Ampel Surabaya \\ E-mail: syihabb056@gmail.com
}

\begin{abstract}
Abstrak: Perkembangan pendidikan dari zaman ke zaman pasti akan selalu diikuti oleh perkembangan teknologi. Pendidikan karakter melalui pembelajaran PAI sangat diperlukan peserta didik pada zaman yang semakin canggih dengan adanya teknologi yang semakin modern. Dengan berkembangnya teknologi dalam dunia pendidikan, teknologi dapat membantu pendidikan dengan menggunakan model pembelajaran modern. Hasil temuan dalam kajian ini adalah teknologi dapat diintegrasikan menggunakan model SAMR ( Subtitusi, Augmentasi, Modifikasi, dan Redefinisi) sehingga mampu meningkatkan mutu pendidikan yang lebih baik. Penulis menganggap integrasi teknologi pada pembelajaran dengan model SAMR sangat diperlukan, sehingga pendidik dapat lebih mudah mencapai tujuan dalam pembelajaran Dalam jurnal ini akan mengulas bagaimana integrasi tekonologi pada pembelajaran PAI dengan menggunakan model SAMR.
\end{abstract}

Kata Kunci: Pembelajaran, PAI, SAMR

Abstract: The development of education from time to time will always be followed by technological developments. Character education through Islamic Education learning is needed by students in an increasingly sophisticated era with increasingly modern technology. With the development of technology in the world of education, technology can help education by using modern learning models. The findings in this study are that technology can be integrated using the SAMR (Substitution, Augmentation, Modification, and Redefinition) model so that it can improve the quality of education better. The author considers that technology integration in learning with the SAMR model is very necessary, so that educators can more easily achieve goals in learning. In this journal, we will review how technology integration in Islamic Education learning using the SAMR model.

Keyword: learning, Islamic education, SAMR 


\section{Pendahuluan}

Era revolusi industri 4.0 ditandai dengan semakin masifnya pengaruh teknologi informasi dalam berbagai kebutuhan kehidupan manusia. Berkembangnya teknologi yang semakin pesat menciptakan berbagai perubahan demikian juga perubahan dalam dunia pendidikan. Perubahan yang berkaitan dengan proses belajar mengajar, media pembelajaran, model pembelajaran, teknis pelayanan pendidikan, serta hal-hal lain yang menyangkut dalam pendidikan. Dengan demikian guru dan tenaga kependidikan harus menyiapkan diri untuk mengahadapi perubahan tersebut, agar pendidikan yang diberikan kepada peserta didik sesuai dengan era 4.0 saat ini. Peserta didik yang saat ini sangat peka terhadap perubahan teknologi. Guru harus bisa mengimbangi karakteristik tersebut, guru dituntut untuk siap mengubah dan meningkatkan kegiatan pembelajaran dengan cara mengintegrasikan teknologi ke dalam kegiatan pembelajaran. Guru PAI selain memiliki tanggung jawab untuk mengajarkan materi dan mempraktikkannya, juga bertanggung jawab membentuk akhlak peserta didik. Tanggung jawab yang dibebankan kepada guru PAI akan lebih ringan jika dibantu dengan adanya teknologi dalam pembelajaran seperti halnya dalam mengajarkan tentang sejarah atau kejadian hari akhir dengan menggunakan teknologi berupa alat elektronik lcd proyektor dengan menampilkan video akan lebih mudah dipahami peserta didik.

Untuk meningkatkan kegiatan pembelajaran PAI, guru dapat mempertimbangkan penggunaan model SAMR (Subtitusi, Augmentasi, Modifikasi, dan Redefinisi). Teknologi dapat membantu seorang guru untuk menciptakan proses pembelajaran efektif dan tepat. Namun masih banyak guru yang belum bisa mengintegrasikan teknologi ke dalam pembelajaran. Seperti penelitian yang dilakukan oleh Rohmad menyimpulkan bahwa sebagian pembelajaran PAI masih bersifat teacher-centered, dimana pembelajaran masih berpusat pada guru, tanpa memberikan banyak kesempatan kepada peserta didik untuk mengeksplorasi pengetahuannya. ${ }^{1}$ Dengan demikian, artikel ini akan membahas Integrasi teknologi pada pembelajaran PAI dengan menggunakan model SAMR (Subtitusi, Augmentasi, Modifikasi, dan Redefinisi ).

\section{Sekilas tentang Teknologi Pendidikan Model SMAR}

Dalam teknologi pendidikan yang menjadi landasan pemanfaatan segala macam bentuk teknologi baik yang bersifat hardware maupun software, diperuntukkan mempermudah proses kegiatan belajar mengajar sehingga menjadi lebih efektif dalam

\footnotetext{
${ }^{1}$ Rohmad Ms, "Kompetensi Guru PAI dalam Pembelajaran Berbasis Teknologi Informasi," ISLAMICA: Jurnal Studi Keislaman 8, no. 1 (September 2, 2013), 241.
} 
pelaksanaannya. Teknologi pendidikan mampu menjawab berbagai problem-problem yang ada dalam banyak sektor pendidikan. Komputer dan internet semisal, dalam semua kegiatan belajar mengajar seperti penulisan, penugasan serta penilaian dapat dipermudah dengan adanya teknologi pendidikan. ${ }^{2}$ Ada berbagai cara yang dapat dimanfaatkan dalam pendidikan menggunakan kecangihan teknologi, seperti halnya dalam pembelajaran PAI guru dapat menggunakan Model Subtitusi, Augmentasi, Modifikasi, dan Redefinisi (SAMR).

Model SAMR dikembangkan Ruben Puentedura karena beberapa pekerjaan yang dia lakukan pada pertengahan 80-an. ${ }^{3}$ Model Subtitusi, Augmentasi, Modifikasi, dan Redefinisi (SAMR) ialah:

1. Substitution: Teknologi digunakan sebagai pengganti peralatan yang dipakai dengan tidak ada perubahan fungsi.

2. Augmentation: Teknologi digunakan sebagai pengganti peralatan yang dipakai dengan adanya penambahan atau perbaikan fungsi.

3. Modification: Teknologi memungkinkan untuk mengubah cara kerja kita menjadi lebih baik.

4. Redefinition: Teknologi memungkinkan untuk menciptakan cara kerja yang bahkan tidak pernah kita banyangkan sebelumnya. ${ }^{4}$

\section{Kerangka Kerja Operasional Model SMAR dalam Pembelajaran PAI}

Dalam teknologi pendidikan yang menjadi landasan pemanfaatan segala macam bentuk teknologi baik yang bersifat hardware maupun software, diperuntukkan mempermudah proses kegiatan belajar mengajar sehingga menjadi lebih efektif dalam pelaksanaannya. Teknologi pendidikan mampu menjawab berbagai problem-problem yang ada dalam banyak sektor pendidikan. Komputer dan internet semisal, dalam semua kegiatan belajar mengajar seperti penulisan, penugasan serta penilaian dapat dipermudah dengan adanya teknologi pendidikan. Dalam pembelajaran PAI dikenal dengan pembelajaran yang sering mengunakan metode pembelajaran ceramah dimana guru menerangkan serangkaian materi pembelajaran dan peserta didik mendengarkan, sehingga seringkali uampan balik dari pemahaman siswa tidak terlihat. Dan mengerjakan soal tanya jawab tertulis yang paling

\footnotetext{
${ }^{2}$ Suparman Dan Zuhairi, Pendidikan Jarak Jauh Teori Dan Praktek, Jakarta: Pusat Penerbitan Universitas Terbuka, 2004

${ }^{3}$ Evi Fatimatur Rusydiyah, Teknologi Pembelajaran Implementasi Pembelajaran Era 4.0, (Surabaya: Uin Sunan Ampel Press, 2019), 89.

${ }^{4}$ Hamilton, E.R, Rosenbarg J.M, Akcaoglu, M "The Substitution, Augmentation, Modification, Redefinition (SAMR) Model" a critical Review and suggestions for us" (Association For Educational Communication \& Technology 2016)
} 
populer digunakan untuk mengambil penilaian kegiatan belajar mengajar, sehingga seringkali peserta didik merasa bosan dengan pembelajaran yang seperti ini.

Oleh sebab itu memanfaatkan teknologi sudah menjadi kebutuhan primer yang tidak bisa terelakkan lagi pada suatu sistem pendidikan yang efektif. Dari sekian banyak negara maju adalah mereka yang menerapkan integrating of technology pada setiap pembelajaran. Semua hal ini tidak akan bisa diterapkan tanpa adanya kapasitas guru yang kurang kompeten sehingga tantangan utama dalam penegakan teknologi pada sektor pendidikan adalah bagaimanana guru dituntut untuk terampil dan mengikuti kapasitas yang diperlukan dalam basis pengetahuan dan pendidikan. Pemerintah telah menganjurkan dalam bingkai kebijakan pendidikan dan kurikulum nasional bahwa beberapa jenis skill yang harus diasah dan membutuhkan semangat maupun support yang besar adalah mengenai pertumbuhan informasi dalam repository di seluruh dunia. Dampaknya siswa lebih mampu mengembangkan literasi informasi dan keterampilan pada setiap sumber-sumber yang diakui dan sudah terbukti pada hasil risetnya. ${ }^{5}$

Keberhasilan seorang guru tidak terlepas dari kemampuan guru mengoptimalkan kreativitasnya. Kreativitas serta aktivitas guru harus mampu menjadi inspirasi bagi para peserta didik. Sehingga peserta didik akan lebih terpacu motivasinya untuk belajar, berkarya dan berkreasi. Guru berperan aktif dalam pengambangan kreativitas siswa, yaitu dengan memiliki karakteristik pribadi guru yang meliputi motivasi, kepercayaan diri, rasa humor, kesabaran, minat dan keluwesan (fleksibel) serta guru dapat menggunakan model pembelajaran yang meneyenangkan yang sesuai dengan zaman. Guru yang kreatif mempunyai semangat dan motivasi tinggi sehingga bisa menjadi motivator bagi peserta didiknya untuk meningkatkan dan mengembangkan kreativitasnya, khususnya yang tertuang dalam sebuah bentuk pembelajaran yang inovatif. Artinya selain menjadi seorang pendidik, guru juga harus menjadi seorang kreator yang mampu menciptakan kondisi belajar yang nyaman dan kondusif bagi peserta didik dalam rangka mewujudkan hasil belajar peserta didik yang maksimal. Dapat dipahami bahwa, kedudukan guru menjadi titik sentral dan awal dari semua pembangunan pendidikan, karena itu tanpa guru, maka dunia pendidikan tidak memiliki arti yang signifikan. Posisi guru dalam pelaksanaan pendidikan berada pada garda terdepan,

\footnotetext{
5 Hendri Fitriadi, Integrasi Teknologi Informasi Komunikasi Dalam Pendidikan Potensi Manfaat Masyarakat Berbasis Pengetahuan Pendidikan Nilai Strategi Implementasi Dan Pengembangan Profesional, Jurnal Pendidikan Teknologi Dan Kejuruan Volume 21 Nomor 32013 Halaman 268-270
} 
keberadaan dan kesiapannya menjalankan tugas sebagai pendidik, sangat menentukan bagi terselenggaranya suatu proses pendidikan. ${ }^{6}$

Maka dari itu dengan adanya kecanggihan sistem teknologi bisa menjadi support tehadap segala aspek pada pendidikan. ${ }^{7}$ Teknologi di sekolah, yang banyak dipahami sebagai penggunaan komputer atau alat bantu belajar yang menggunakan alat elektronik, Pemahaman tentang penggunaan teknologi dalam pembelajaran di kelas sangat menarik karena benarbenar akan mempermudah penyampaian materi yang akan diajarkan guru kepada peserta didik. akses teknologi dalam bingkai pendidikan, yang memunculkan inovasi istilah, teknik, model, sistem, perangkat, dan lainnya. Tidak ada dalam teknologi, sesuatu yang bersifat negatif bila dipahami bahwa teknologi adalah bahan pembantu dalam mengintegrasikan pendidikan dan pemecah masalah yang ada pada lingkup terbatas maupun tidak terbatas. ${ }^{8}$

Model pembelajaran SAMR (Subtitusi, Augmentasi, Modifikasi, dan Redefinisi) dapat diintegrasikan dalam kegiatan pembelajaran PAI, Berikut ini penerapan Fungsional (SAMR) Substitution, Augmentation, Modification, Redifinition Model. ${ }^{9}$ Menurut Ruben R. Puentedura selaku peneliti model ini, telah mengembangkan apa model SAMR. Sebuah model yang menyediakan kerangka kerja untuk menunjukkan dampak teknologi pada pengajaran dan pembelajaran. Model SAMR ini bergerak melalui berbagai tahap, mulai dari tingkat pembelajaran dasar pada fase tranformation hingga ke tingkat dimana pembelajaran bersifat transformasi pada tinkat enhancemen. Model SAMR dapat mengukur parameter sejauhmana teknologi dapat membantu pembelajaran. SAMR memiliki peran penting karena memungkinkan kita untuk berpikir tentang bagaimana pembelajaran dapat dipermudah melalui penggunaan teknologi. ${ }^{10}$

Berikut ini penerapan Fungsional SAMR Model:

1. Substitution: Teknologi digunakan sebagai pengganti peralatan yang dipakai dengan tidak ada perubahan fungsi, seperi dalam pembelajaran PAI pada materi kisah para nabi bisa dimulai dengan cara guru menceritakan kisah salah satu nabi kemudian peserta didik diminta untuk menulis ulang cerita yang telah disampaikan guru serta mengambil hikmah

\footnotetext{
${ }^{6}$ Tanwir \& Hamdanah Said inovasi pembelajaran guru pendidikan agama islam berbasis teknologi informasi, Kuriositas: Media Komunikasi Sosial dan Keagamaan Vol. 11 No.2, Desember 2018: h.190

7 Suparman Dan Zuhairi, Pendidikan Jarak Jauh Teori Dan Praktek, Jakarta: Pusat Penerbitan Universitas Terbuka, 2004

${ }^{8}$ Setijadi, Definisi Teknologi Pendidikan, (Jakarta: Raja Grafindo Persada, 1994), 1

${ }^{9}$ Wiil Fastigi “ Technology For Learners” https://technologyforlearners.com/the-samr-model/; diakses tanggal 11 Maret 2020

${ }^{10}$ Hamilton,E.R, Rosenbarg J.M, Akcaoglu,M “ The Substitution, Augmentation, Modification, Redefinition (SAMR) Model" a critical Review and suggestions for us" ( Association For Educational Communication \& Technology 2016)
} 
dalam cerita tersebut. Dalam kegiatan ini peserta didik dapat menuliskan tugasnya pada komputer, laptop atau tablet pada aplikasi microsoft word.

Sehingga penulisan tersebut masuk dalam kategori subtitution, jika peserta didik sudah terbiasa menganti penulisan secara manual dengan teknologi, guru bisa melanjutkan kegiatan belajar mengunakan augmentation.

2. Augmentation: Teknologi digunakan sebagai pengganti peralatan yang dipakai dengan adanya penambahan atau perbaikan fungsi.

Yang mulanya peserta didik hanya mengunakan teknologi sebagai alat ganti pada tahap ini lebih difungsikan menjadi hal yang lebih mempermudah pembelajaran. Peserta didik bisa diajarkan bahwa dalam teknologi yang digunakan ada cara pengecekan kata dan kalimat sehingga kalimat yang ditulis bisa sesuai dengan tata bahasa yang ada, bisa juga dengan memasukkan gambar, misalnya pada materi wudhu. Peserta didik bisa memasukkan gambar pada tugas mengurutkan tatacara berwudhu, dengan demikian microsoft word yang mulanya hanya digunakan untuk menulis bisa juga di fungsikan untuk memperjelas materi dengan adanya gambar. Jika sudah pada tahap ini peserta didik sudah terbiasa mengntegrasikan teknologi dalam pembelajaran, guru bisa melanjutkan pada tahap yang lebih inovatif dengan Modification.

3. Modification: Teknologi memungkinkan untuk mengubah cara kerja kita menjadi lebih baik. Dengan hasil kegiatan belajar yang telah diselesaikan peserta didik misalnya pada pembuatan poster wudhu dalam aplikasi microsoft word, guru bisa menyediakan jaringan internet. Sehingga yang tadinya hasil itu hanya dapat dikumpulkan berupa file atau ditampilkan hanya dalam ruangan kelas, kini dengan adanya jaringan internet peserta didik diminta untuk membagikan hasil karyanya pada ruang publik misalnya dengan membuat blog yang dapat dimuat dan dilihat pada dunia maya secara umum, kemudian dapat saling memberikan masukan, komentar pada tugas yang telah diselesaikannya. Jika dalam tahap ini peserta didik telah dapat mengunakan dan menikmati manfaat teknologi dengan segala kemudahannya, guru dapat melanjutkan pada kegiatan yang lebih kompleks yaitu Redefinition.

4. Redefinition: Teknologi memungkinkan untuk menciptakan cara kerja yang bahkan tidak pernah kita banyangkan sebelumnya.

Peserta didik bisa semakin mengembangkan apa yang telah dipahaminya mulai dari penulisan, dikolaborasi dengan berbagai gambar dan lain sebagainya, kemudian mendapat komentar, diedit dan kemudian bisa di praktekkan dan kegiatan tersebut bisa dibuat video dan diupload di youtube, sehingga jika menjadi tugas kelompok peserta 
didik akan saling berlomba-lomba memahami materi yang disampaikan guru sehingga dalam memgerjakan tugas menggunakan teknologi lebih menyenangkan dan mempermudah proses belajar mengajar.

Selain itu, kemampuan berkolaborasi dengan teknologi juga diperlukan oleh peserta didik. Dengan berkolaborasi, wawasan dan pengetahuan akan semakin luas. Kolaborasi dalam sebuah pembelajaran dilakukan melalui berbagai interaksi dimana proses interaksi merupakan bagian penting dari sebuah pembelajaran. ${ }^{11}$ Peran teknologi dalam membentuk kemampuan kolaborasi peserta didik adalah tidak adanya batas ruang dan waktu pada peserta didik dalam berinteraksi dan berkolaborasi satu sama lain. Hal ini sebagaimana penelitian yang dilakukan oleh Anwaril Hamidy dan Dyah Purboningsih terkait pembalajaran kolaboratif berbasis online pada perkuliahan filsafat menunjukkan bahwa penggunaan teknologi berbasis online ini mampu meningkatkan kemampuan berpikir serta lebih partisipatif dalam menuliskan pemikirannya di jejaring online. ${ }^{12}$

Kemampuan lain yang dibutuhkan oleh peserta didik adalah kemampuan berpikir kritis. Dengan berpikir kritis, peserta didik ditantang membaca berbagai masalah dan dampaknya terhadap lingkungan sosial serta mengenali tantangan adalah langkah awal untuk perkembangan. ${ }^{13}$ Untuk menunbuhkan kemampuan berpikir kritis para peserta didik harus memiliki motivasi. Disinilah peran dari sebuah teknologi, yaitu untuk membantu menumbuhkan motivasi belajar pada peserta didik.

\section{Penutup}

Teknologi pendidikan merupakan rangkaian sistem yang kompleks yang mampu membantu terlaksananya pendidikan menjadi efektif serta efisien. Dalam pembelajaran PAI teknologi dapat terintegrasi dengan mengunakan model SAMR yaitu Substitution: Teknologi digunakan sebagai pengganti peralatan yang dipakai dengan tidak ada perubahan fungsi. Augmentation: Teknologi digunakan sebagai pengganti peralatan yang dipakai dengan adanya penambahan atau perbaikan fungsi. Modification: Teknologi memungkinkan untuk mengubah cara kerja kita menjadi lebih baik. Redefinition: Teknologi memungkinkan untuk menciptakan cara kerja yang bahkan tidak pernah kita banyangkan sebelumnya.

\footnotetext{
11 Anwaril Hamidy and Dyah Purboningsih, "Pembelajaran Kolaboratif Berbasis Online Dalam Perkuliahan Filsafat Pendidikan Matematika," PRISMA, Prosiding Seminar Nasional Matematika (February 1, 2016 ), 139.

${ }^{12}$ Ibid., 143.

${ }^{13}$ Larry W. Riggs and Sandra Hellyer-Riggs, "Development and Motivation in/for Critical Thinking," Journal of College Teaching \& Learning 11, no. 1 (2014), 1-8.
} 
Dari uraian diatas penulis dapat mengambil kesimpulan terkait integrasi teknologi pada pembelajaran PAI dengan mengunakan model SAMR (Substitution, Augmentation, Modification, Redefinition) merupakan rangkaian model pembelajaran yang dilakukan secara bertahap sehingga dalam pelaksanaannya siswa tidak merasa kesulitan dengan adanya teknologi melainkan siswa merasa bahwa teknologi mempermudah dalam proses pembelajaran terkhusus pada pelajaran pendidikan Agama Islam. Dengan banyaknya manfaat teknologi diantaranya mengunakan model SAMR yang akan mampu menjadikan proses pembelajaran dapat lebih maksimal perlu diketahui juga bahwa tidak ada model belajar yang paling benar dan sempurna, kita harus mampu menggunakan model SAMR tersebut sesuai dengan situasi dan tujuan pembelajaran.

\section{Daftar Rujukan}

E.R, Hamilton, Rosenbarg J.M, and Akcaoglu,M. “ The Substitution, Augmentation, Modification, Redefinition (SAMR) Model" a critical Review and suggestions for us", Association For Educational Communication \& Technology, 2016.

Hamidy, Anwaril and Dyah Purboningsih. "Pembelajaran Kolaboratif Berbasis Online Dalam Perkuliahan Filsafat Pendidikan Matematika," PRISMA, Prosiding Seminar Nasional Matematika, February 1, 2016

Hendri Fitriadi, Integrasi Teknologi Informasi Komunikasi Dalam Pendidikan Potensi Manfaat Masyarakat Berbasis Pengetahuan Pendidikan Nilai Strategi Implementasi Dan Pengembangan Profesional, Jurnal Pendidikan Teknologi Dan Kejuruan Volume 21 Nomor 32013

Ms, Rohmad. "Kompetensi Guru PAI dalam Pembelajaran Berbasis Teknologi Informasi," ISLAMICA: Jurnal Studi Keislaman 8, no. 1 September 2, 2013

Riggs, Larry W. and Sandra Hellyer-Riggs. "Development and Motivation in/for Critical Thinking," Journal of College Teaching \& Learning 11, no. 1 (2014).

Rusydiyah, Evi Fatimatur. Teknologi Pembelajaran Implementasi Pembelajaran Era 4.0. Surabaya: Uin Sunan Ampel Press. 2019.

Setijadi. 1994. Definisi Teknologi Pendidikan. Jakarta: Raja Grafindo Persada.

Suparman Dan Zuhairi, Pendidikan Jarak Jauh Teori Dan Praktek, Jakarta: Pusat Penerbitan Universitas Terbuka, 2004

Tanwir \& Hamdanah Said inovasi pembelajaran guru pendidikan agama islam berbasis teknologi informasi, Kuriositas: Media Komunikasi Sosial dan Keagamaan Vol. 11 No.2, Desember 2018: h.190

Wiil Fastigi “ Technology For Learners” https://technologyforlearners.com/the-samr-model/; diakses tanggal 19 Maret 2020 